\title{
The Improvement of the Agricultural Yields Forecasting Model Using the Software Product "Land Viewer"
}

\begin{abstract}
Using the data of the remote sensing the Earth, new opportunities in assessing the state of agricultural crops and yield forecasting have been considered. In addition to the above-ground information, as shown by numerous studies conducted earlier, most parameters of the germination and development of agricultural crops can be restored and used from satellite images. Thanks to the software product "Land Viewer", which enables pictures to be taken from Landsat 4, 5, 7, 8, Sentinel 2 and Terra satellites, and it will provide improving the model and assessment of the biomass potential of agricultural crops. The data obtained from remote sensing during the cropping season, show the information on the condition of agricultural crops sown according to the vegetation stages (photosynthesis process) in crops. At various levels of development, in terms of the Normalized Difference Vegetation Index (NDVI), the seasonal pattern of crops photosynthesis is well reflected, which is associated with the above-ground biomass. The results have been presented in the current model of crop yield forecasting. The improved forecasting model enables significant increases in the economic efficiency of the research, and ensure the accuracy of the data on the physiological processes of agricultural crops, yields, and efficiency of obtaining the data on the research object.
\end{abstract}

Keywords: pictures from satellites, programmatic interface "Land Viewer", Normalized Difference Vegetation Index

Received: 20 June 2019; accepted: 2 July 2019

(C) 2020 Authors. This is an open access publication, which can be used, distributed and reproduced in any medium according to the Creative Commons CC-BY 4.0 License.

1 Lviv National Agrarian University, Department of Geodesy and Geoinformatics, Lviv, Ukraine, email: pavlokolodiy@gmail.com ORCID ID: https://orcid.org/0000-0001-9847-9520

2 Lviv National Agrarian University, Department of Geodesy and Geoinformatics, Lviv, Ukraine, email: marimari198408@gmail.com

ORCID ID: https://orcid.org/0000-0002-1317-2018 


\section{Introduction}

The main tendencies of the quality of satellite data have been influenced by the development of new technologies in recent years. Due to United States Geological Survey (USGS) we can get free of charge spectrazonal images that are constantly updated. Access to it is provided by the American government research organization. The American company, EOS Data Analytics, was founded by a Ukrainian, Maxim Polyakov, and specializes in the evaluation and processing of large GIS data.

\section{Case Study}

Earth remote sensing (ERS) is used to obtain the operational information for an objective assessment of the crop condition of (quantitative and qualitative indicators of changes in crop cultivation, receiving the information about processing by means of chemicalization) over large areas. The use of land-based activities data is an additional condition for the efficient decryption of aerospace data [1].

The unique opportunity to use satellite imagery data sources to gather reliable information about the crop condition, taking into account environmental peculiarities and area estimation, yield forecasting and monitoring, is provided by the software product "Land Viewer". Using the program today is much easier than in the past and over the past 5 months the developers have improved the program and filled the archives with valuable data (images obtained from space):

- from 1982 to 1992 - Landsat 4 satellite,

- from 1992 to 2013 - Landsat 5 satellite,

- from 1999 - Landsat 7 satellite,

- from 2013 to 2017 - Landsat 8 satellite,

- from 2013 to 2017 - the Modis scanner of the Terra satellite,

- from 2013 to 2017 - the Sentinel 2 satellite.

The "Land Viewer" software requires a user registration but is very convenient for work. It is necessary to choose an orbital image from the satellite, which will better display the investigated area and visualize it in the image. The images contain detailed information about the characteristics of crops, which allows the necessary work data to be saved. To access the data there is no need to install various software for different satellites and download voluminous archives of images for a certain period. Thanks to such possibilities, the study guarantees the accuracy of the chosen outgoing data.

An improved model for agricultural crop yields forecasting can be implemented while replacing the parameters of the basic model by the parameters proposed by the set of Band Combinations extensions. Having selected the necessary satellite from the proposed program, it is needed to analyze their characteristics to achieve 
stated research targets. The Landsat 8 and Sentinel 2 satellites differ in their resolutions of received images of $30 \mathrm{~m}$ and $10 \mathrm{~m} /$ pixel, respectively. The Landsat 8 satellite receives data using two sets of tools: the Operational Land Imager (OLI) and the Thermal Infra-Red Sensor (TIRS). The first set receives the image in 9 ranges of the visible world and near infrared radiation (ICh), the second set, in 2 ranges of the far (thermal) IR. Range 5 measures the near-infrared spectrum. This part of the spectrum is very important for calculating the vegetation index, since the water in healthy plants shows it. One of the most common indices for solving problems while using quantitative assessment of the vegetation cover enables measuring the degree of plant health more precisely than if we simply estimated the visible greenery in the researched area. For a positive result of the research, it is necessary to analyze images in other ranges. To model plant physiological processes, it is essential to use the spectrum with the NDVI (Normalized Difference Vegetation Index). This normalized relative vegetation index is a simple quantitative indicator of the amount of photosynthetic active biomass (vegetation index) [2].

The different areas of shortwave infrared light (SWIR) enable dry lands and wet lands, as well as snow and water, to be distinguished, which is very important during the growing season of crops. With the help of multispectral data of the Sentinel 2 satellite it is possible to obtain high-resolution images. In the visible, infrared (VNIR) and shortwave infrared (SWIR) zones of the spectrum, which include 13 spectral channels, this guarantees that differences in the vegetation conditions will be revealed, including temporary changes, and also minimizes the impact on the quality of imagery. Increasing the bandwidth of the view, alongside with the high repeatability of surveys, will allow to monitor processes that are changing rapidly such as the intensive growth of agricultural crops. It is also important to predict the change in the nature of growth or ripening of vegetation during the growing season in the researched area using the example of Vinnytsia region. The equipment of an optoelectronic multispectral sensor for surveys with a resolution 10-60 $\mathrm{m}$ in the visible and near-infrared (VNIR) and shortwave infrared (SWIR) spectral zones, which include 13 spectral channels, this guarantees revealing the differences in the vegetation conditions, including temporary changes, and also minimizes the impact on the quality of imaging the atmosphere. At the first stage of the study, it is necessary to establish remote measurements at the beginning of the growing season of agricultural crops (winter wheat, winter rape). To assess the biomass potential of these crops, we chose a satellite that better reflects the visibility and clarity of the image. In the software product "Land Viewer", we specify the coordinates of the researched territory using the extensions of Band Combinations [3], and create a snapshot of the Agriculture combination. Using the methods of satellite images examination, the authors analyze the growth of agricultural crops to determine their conditions [4]. A snapshot of the Sentinel 2 satellite reflects the sprouting of agricultural crops rather well on June 5, 2018 (Fig. 1). 


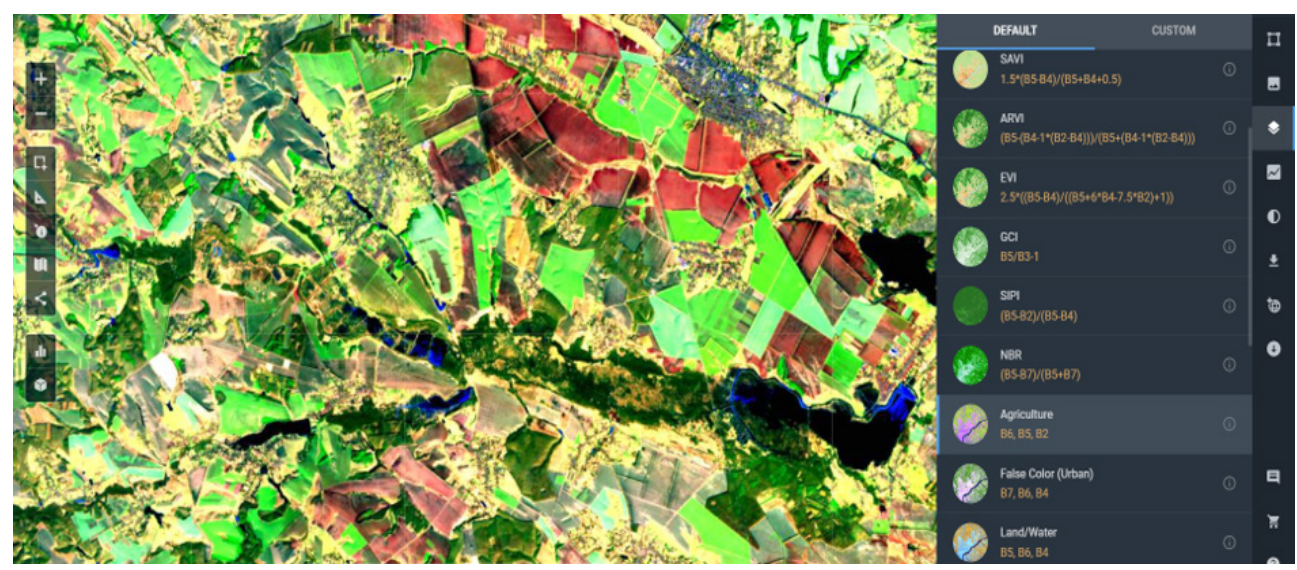

Fig. 1. Display of ranges - June. 5, 2018

Source: [5]

Figure 1 clearly shows the condition of the researched crops (winter wheat, winter rape), the areas of crops reflect leaf surface due to the vegetative index of spring crops NDVI. Moreover, the Normalized Difference Vegetation Index of arable lands is also displayed on the areas of red and pink colors where crops have not yet sprouted [6]. The essential information of the arable lands index gives an opportunity to evaluate the capacity of moisture in the soil, thanks to this it is also possible to forecast the development of crops in the future, for example, after 32 days. Soil moisture is reflected in red and pink colors, depending on the capacity of moisture in it. On the research land plots we may see high-grade moisture content, which will enable developing crops in the future leaf surface. After overwintering, the condition of winter crops is mainly assessed by differences in the color of healthy and dead plants. Considering this research object, certain conclusions about the favorable conditions for crops development can be drawn.

The assessment of the same terrain to recheck the leaf surface can be conducted using the Sentinel 2 images. The "earing" or "flowering" phase of grain crops on July 5, 2018 is presented (Fig. 2).

Data of the satellite Sentinel-2 supply services GMES, connected with the management of land resources and agricultural production is supplied by GMES services. The unique nature of the mission of Sentinel 2 stems from its combination of large territorial coverage, repetitive imaging and, consequently, it systematically obtains complete coverage of the earth by means of a multi-spectral survey with a high resolution. The equipment of an optical-electronic multi-spectral sensor for survey with the resolution 10-60 $\mathrm{m}$ in a visible, nearest infrared (VNIR) and shortwave infrared (SWIR) zones of a spectrum, containing 13 spectral channels, secures the depiction of differences in vegetation conditions, including temporary changes, as well as minimizing the impact of air on the survey. The orbit, with the average height of 
$785 \mathrm{~km}$, and availability of two satellites in the mission, supports a repetitive survey every 5 days on the equator and every 2-3 days at middle latitudes. In such systems, radiation comes to the corresponding sensors, generating electric signals depending on radiation intensity. Software support regulates the possibility of sorting out images referring to similar data and quality of the picture.

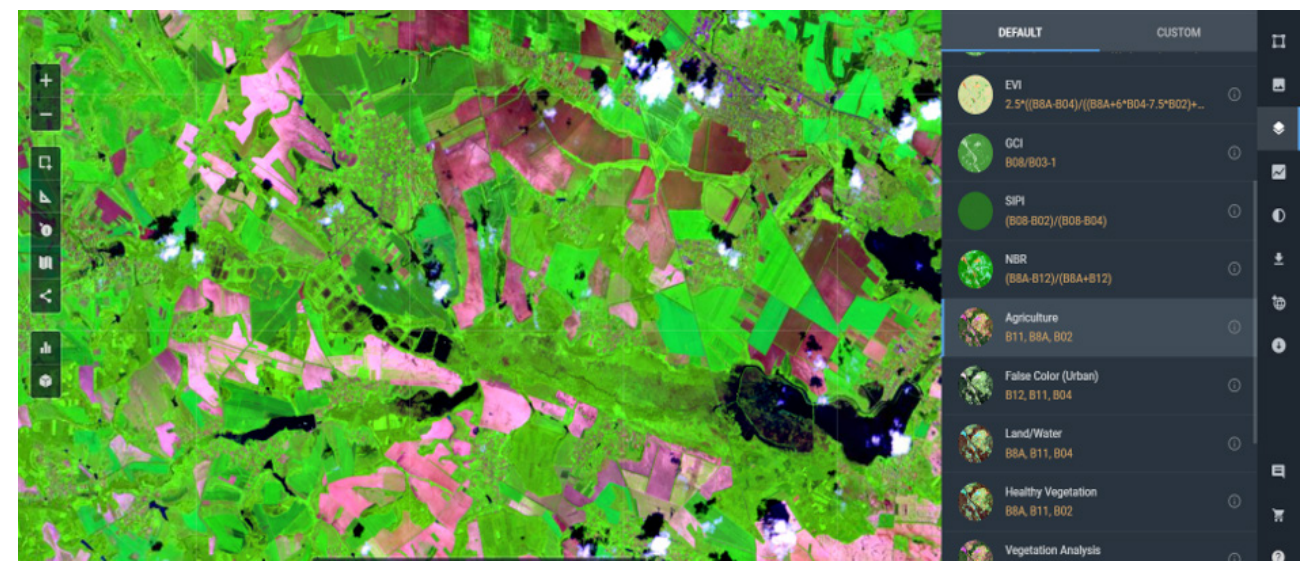

Fig. 2. The "earing" or "flowering" phase of grain crops - July. 5, 2018

Source: [7]

Images of the studied territory are differentiated by space resolution (10-500 $\mathrm{m} /$ pixel), by periods of repetitive visiting (2-16 days) and by the content of band of wavelengths (4-12 band). Data from the Sentinel 2 and Landsat 8 OLI and TIRS, data of Landsat ETM+, coming from operating satellites, are regularly updated and immediately available for review, analysis or loading. The band of wavelengths of satellite data are widely used for the preliminary processing of pictures (air correction, increase of image definition) and the processing of images (land use, classification of vegetation cover and others).

The best resolution is observed in the satellite data from Sentinel: $10-20 \mathrm{~m} /$ pixel, which is sufficient for monitoring of crop growing or monitoring of forest fell. The level increased in comparison with the previous snapshot, taken 32 days before. We are researching the growth of crops which have high economic potential: winter wheat, winter rape, maize for grain, sunflower.

Arable land with an insignificant leaf area of the crops is depicted on the red and pink areas (maize for grain, sunflower). The growth dynamics of the leaf surface is also clearly visible (the seasonal variation in the photosynthesis intensity of agricultural crops), which makes it possible to use the vegetation indices. The dynamics of photosynthesis in crops is traced rather well. Identification of different crops makes it possible to create agricultural yields forecasting model for predicting the rapid growth of biomass during the spring-summer period. 
The primary role of the Band Combinations data-processing appears in the indices generated at the user's request in real time. It is very easy to check the image from two satellites and to decide whether it is good for the project.

Estimating the informativeness of hyperspectral aerospace images allows the forecasting of the possibility of combining different sensors of spectral channels while broadening thematic tasks and optimizing the composition of informative spectral channels, improving the quality and efficiency of the interpretation of materials in general.

The researched territory can be visually assessed from the Landsat 8 satellite compared to August 17, 2018 (Fig. 3). The decrease in spectral brightness is clearly observed due to the crops ripening and the harvest of winter wheat and winter rape. Thus, we can see the dependence of the leaf index of maize for grain, sunflower on the NDVI of spring crops. This is reflected in the regressivity of the NDVI level - the ripening of crops. The course of the NDVI level reflects the most significant pattern of plant growth, which in the initial period - the growth rate means a decrease in the intensity of photosynthesis. Considering the fact that NDVI is sensitive to the impact of soil and atmosphere, it is recommended to use additional indices for the more precise analysis of vegetation. The SAVI vegetation index, corrected for the impact of soil, has been developed to minimize the impact of soil brightness. Its author, Huete, introduced the coefficient of the correction of soil $L$ into the NDVI equation to correct the impact of soil noise (soil color, soil humidity, changeability of soil by the regions), which has the tendency to influence results of the studied territory.

The formula of the SAVI vegetation index is:

$$
S A V I=\frac{(N I R-r e d)}{(N I R+r e d+L)} \cdot(1+L),
$$

where $L$ is a variable figure, which varies from -1 to 1 , depending on the amount of green vegetation which is present in the studied territory [6].

To conduct an analysis of the high green vegetation, $L$ is set as zero (in that case, the data of the SAVI index are equal to NDVI). However, in the region with low green vegetation $L=1$ is required. That formula is used for the analysis of young crops, dry regions with thin vegetation (less than $15 \%$ of the total area) and those with an open soil surface. The GCI index is used to study conditions of healthy vegetation. Physical conditions of vegetation are described to assess the share of chlorophyll in the leaves of crops of different kinds of plants. Thus, the intensity of color helps to differentiate healthy plants from those which are not well developed, or dead because of unfavorable conditions. Key fact: Better prediction of chlorophyll amount with the GCI vegetation index can be achieved by using satellite sensors that have broad NIR and green wavelengths. This index can be described by the following formula [3]:

$$
G C I=\frac{(\text { NIR })}{(\text { green })}-1 .
$$


The best forecast of chlorophyll content with the vegetation index GCI can be achieved using satellite sensors which have broad NIR and green wavelengths. The GCI index is used for monitoring of vegetation after the application of pesticides, change of weather conditions, and the assessment of plant health. Consequently, we can forecast high yields of the researched crops [8].

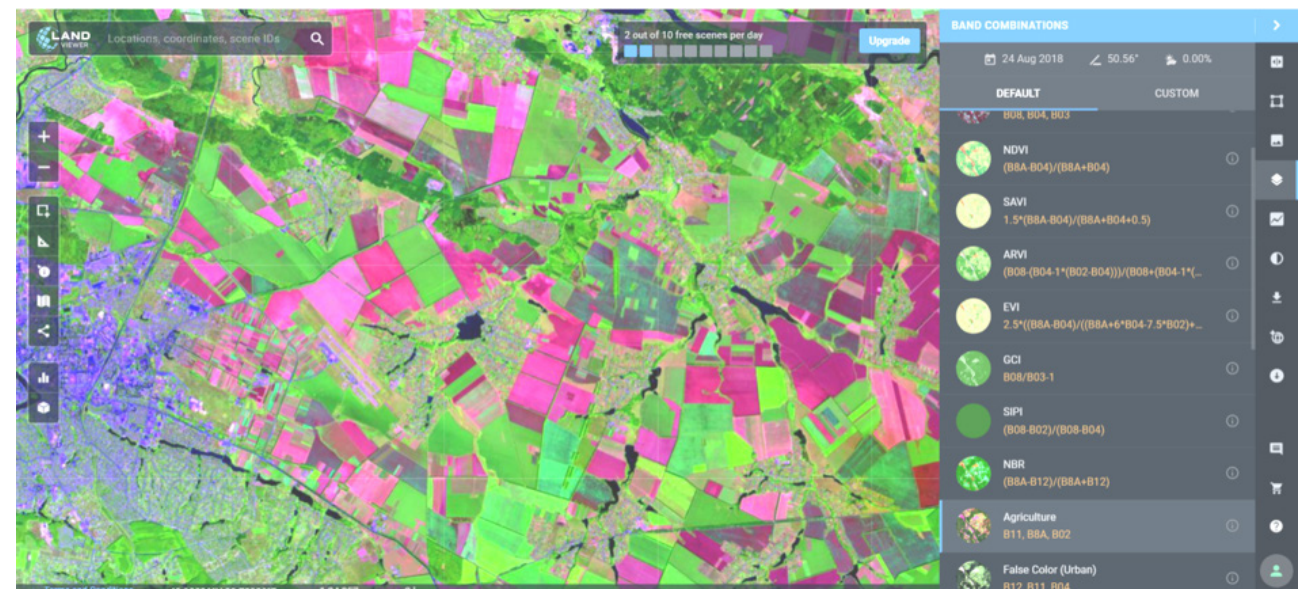

Fig. 3. Growth and ripening of the crops

Source: [9]

To argue credibility of the research in the dynamics of forecasting of the yield of agricultural crops, the authors used statistical data of the agro-industrial sector of Vinnytsia region. For the harvest of 2018, farms of different types sowed 13,776 hectares - winter crops, 3,297 hectares - rapeseeds for grain, 10,479 hectares - wheat for grain. Following the results of the seasonal harvest, Vinnytsia Regional State Administration forecasts that in 2017 the harvest of the early group of grain crops will be 2.5 million tons, it is estimated as 19\% more than in 2016. The yield results exceeded expectations. The average wheat yield was $6.2 \mathrm{t} / \mathrm{ha}$, but the forecasted yield was projected to be $5.8 \mathrm{t} / \mathrm{ha}$. Furthermore, in mid-August, the harvesting of rapeseed was completed (over 12,000 tons were threshed), because there was sufficient rainfall and enough sunny days. These data were based on the collection of information while working in the fields where the research crops sprout [10].

The application of the geo-information method of remote sensing in the research of the improved agricultural yields forecasting model has shown good results. The value of the NDVI is that it characterizes the photosynthesis of agricultural crops (winter wheat, winter rape, maize for grain, sunflower) in the dynamics. On the basis of the obtained data, a spectral profile has been constructed. This spectral profile characterizes the indicators of each crop as it ripens. On the territory of Vinnytsia region, the dependence of the leaf index on its NDVI vegetative index (seasonal 
course of photosynthesis) has been verified, in turn, this enables forecasting of high yields of crops in general. The improved forecasting model of the agricultural crops physiological processes has confirmed the obtained high yields in practice. The provided forecasting model greatly improves the economic efficiency of the research, data accuracy as well as it will ensure the operability of obtaining data about the research object, without driving over vast areas.

\section{Conclusions}

Using the latest software of Band Combinations will allow the necessary information from Landsat 8 and Sentinel 2 satellites to be received with different technical characteristics. New horizons are opening up now due to the capabilities of modern technology for the decisions of thematic tasks in various fields of science. A platform that selects information from geospatial images that were submitted by satellites airplanes and drones, forms the applications that assists to solve the tasks of monitoring in construction, pipeline transport and agriculture. Also, these applications address problems in various fields including industry, water resource management and forestry.

\section{References}

[1] Jensen J.R.: Remote Sensing of the Environment: An Earth Resource Perspective. $2^{\text {nd }}$ ed. Prentice-Hall, Upper Saddle River 2007.

[2] Kolodiy P, Pidlypna M.: The Research of the Agricultural Land Condition Based on Landsat 8 and Sentinel-2 Satellites Data Mergers. [in:] Adamczyk T., Dębińska E. (Eds.), Geographic Information Systems Conference and Exhibition "GIS ODYSSEY 2017", 4th to 8th of September 2017, Trento - Vattaro, Italy: Conference proceedings, Croatian Information Society - GIS Forum, Zagreb, pp. 191-195, http://www.gis.us.edu.pl/index.php?option=com_mtree\&task=att_download\&link_id=744\&cf_id=24 [access: 29.06 .2019 ]

[3] EOS - Earth Observing System, https://eos.com/blog/6-spectral-indexes-ontop-of-ndvi-to-make-your-vegetation-analysis-complete/ [access: 7.07.2019].

[4] Pidlypna M., Kolodiy P.: Improvement of Prediction Models Crop Yields in Software Products Land Viewer [Усовершенствование модели прогнозирования урожайности сельскохозяйственных культур в программном продукте Land Viewer]. International collection of scientific papers of the Global International Scientific Analytical Project participants, 2017: http:/gisap.eu/ node/134508 [access: 29.06.2019]

[5] EOS - Earth Observing System, https://eos.com/landviewer/?lat=49.32456\& $\operatorname{lng}=28.78075 \& z=12 \&$ datasets=4\&id=S2A_tile_20170605_35UPQ_0\&b=SWIR1, Red8,Blue\&anti [access: 7.07.2018]. 
[6] Pettorelli N.: The Normalized Difference Vegetation Index. Oxford University Press, New York 2013. https://www.researchgate.net/publication/233408135_ The_Normalized_Difference_Vegetation_Index_NDVI_Unforeseen_successes_in_animal_ecology [access: 23.06.2019].

[7] EOS - Earth Observing System, https://eos.com/landviewer/?lat=49.32456\& $\operatorname{lng}=28.78075 \& z=12 \&$ datasets $=4 \&$ id $=$ S2B_tile_20180705_35UPQ_0\&b=SWIR1, Red8,Blue\&anti [access: 7.07.2018].

[8] Gitelson A.A., Kaufman Y.J., Merzlyak M.N.: Use of a green channel in remote sensing of global vegetation from EOS. Remote Sensing of Environment, vol. 58, issue 3, 1996, pp. 289-298.

[9] EOS - Earth Observing System, https://eos.com/landviewer/?lat=49.32456\& $\operatorname{lng}=28.78075 \& z=12 \& d a t a s e t s=4 \& i d=S 2 A \_t i l e \_20190824 \_35 U P Q \_0 \& b=S W I R 1$, Red8,Blue\&anti [access: 7.07.2018].

[10] Vinnitsa Regional State Administration - News of RDA [Вінницька обласна державна адміністрація - Новини РДА], http://www.vin.gov.ua/news/ novyny-rda [access: 7.07.2018].

\section{Ulepszenie modelu prognozy plonów upraw w oprogramowaniu "Land Viewer"}

Streszczenie: Jak pokazują liczne badania, większość parametrów kiełkowania oraz stan rozwoju upraw rolnych można określić na podstawie zdjęć satelitarnych. W artykule wskazano nowe możliwości oceny stanu upraw rolnych i prognozowania plonów z użyciem danych teledetekcyjnych. Zastosowano do tego celu oprogramowanie "Land Viewer", które umożliwia wykorzystanie zdjęć z satelitów Landsat 4, 5, 7, 8, Sentinel 2 i Terra oraz poprawę modelu i ocenę potencjału biomasy upraw rolnych. Dane uzyskane za pomocą teledetekcji podczas sezonu upraw dostarczają informacji o stanie roślin na różnych etapach wegetacji (proces fotosyntezy). Na różnych poziomach rozwoju, ocenianego na podstawie znormalizowanego wskaźnika różnicy wegetacji (NDVI), dobrze odzwierciedla się sezonowość fotosyntezy upraw, co jest związane $\mathrm{z}$ biomasą nadziemną. Wyniki zostały przedstawione $\mathrm{w}$ obecnie stosowanym modelu prognozowania plonów. Ulepszony model prognozowania pozwala na znaczne zwiększenie efektywności ekonomicznej badań, a także zapewnia większą dokładność danych o procesach fizjologicznych upraw rolnych, plonach oraz wydajności produkcji w obiekcie badawczym.

\section{Słowa}

kluczowe: zdjęcia satelitarne, interfejs programu „Land Viewer", znormalizowany wskaźnik różnicy wegetacji 